\title{
The Impact of Public Debt on Economic Growth in the Republic of Kosovo
}

\author{
Roberta Bajrami* $^{*}$ Saranda Tafa Fitim Hoxha \\ Faculty of Economics, AAB College, Republic of Kosovo
}

\begin{abstract}
The main purpose of this paper is to examine the impact of public debt in relation to economic growth. The current public debt and economic growth surveys show that the threshold where public debt yields positive results in GDP growth for transition countries is $30-50 \%$ of GDP and from this level or above, there are negative effects in economic growth. Based on this data, this paper analyzes the current public debt and its effects in the future in the Republic of Kosovo. The methodology used in this paper is through the empirical method. The data were analyzed through the R program and they showed the impact of public debt in economic growth in the Republic of Kosovo. By using the VAR (vector autoregression) model, the impact of public debt was measured, as well as the government expenditure, gross fixed capital formation, and gross saving on economic growth in the Republic of Kosovo for the period of 2008 to 2018. The results suggest that Republic of Kosovo achieved higher growth rates when the public debt-to-GDP ratio was around 10-30 percent
\end{abstract}

Keywords: Public Debt, Economic Growth, VAR model

DOI: $10.7176 / \mathrm{JESD} / 11-18-06$

Publication date:September $30^{\text {th }} 2020$

\section{INTRODUCTION}

Analyzing different research on public debt and economic growth in different countries in panel and time series data, we see different causal findings (positive and negative correlations between public debt and economic growth). According to the authors in panel data and time series data Reinhart and Rogoff(2010) and Pattillo (2011), Wigger (2009), Greiner (2012), Taylor (2012), Savvides (1992); Kourtellos, Stengos, and Tan (2012) public debt has a positive impact on economic growth in short term and long term. On the other hand, Ugo Panizza and Andrea F. Presbitero (2013), Cochrane (2011), Lof and Malinen (2014), Calderon and Fuentos (2013), in panel data findings that public debt have a negative effect on economy growth. In time series data Atique and Malik (2012), Bader and Magableh (2009), Ahmed (2015), Boboye and Ojo (2012) conclude that public debt and external debt have a negative effect on economy growth. Also, some authors' findings indicate the threshold effects on public debt in growth. In transition country, the threshold is between $40 \%$ until $50 \%$ of GDP. Any eventual increase in the public debt above the threshold set affect negatively on economic growth (Jernej Mencinger Alexander Aristovnik, Miroslav Verbic (2015), Checherita and Rother (2010), Reinhart and Rogoff (2010), Afonso and Alves (2015), Bexheti et al (2020).

Referring to this research, the main aim of this paper is to empirically analyze the nexus between public debt and economic growth in the Republic of Kosovo for the time spin $2008-2018$. The VAR model in R studio program was used to find the results for this paper. In this paper, we see that there is a positive relationship between public debt and economic growth but the results are not significant. This paper also examines the extent to which Kosovo can increase public debt and have economic growth.

Although, recent evidence has shown a high debate among scholars, the remained central question of such debate refers to the heterogeneous of the effect of the public debt/GDP ratio. Thus, in order to asses these polemics, the following research questions have been raised:

- Does public debt matter for the economic growth in Republic of Kosovo?

- What is the effect of public debt on real GDP in the Republic of Kosovo?

In addition, the following research hypotheses have been established to address the abovementioned research questions:

- $\quad H_{1}$ : Public debt and government expenditures do not have significant impact on GDP.

- $\mathrm{H}_{2}$ : consumption, gross savings and fixed capital formation have positive effect on GDP.

This paper is important for the decision-making of political actors for the freedom of public debt which would stimulate future economic growth.

\section{LITERATURE REVIEW}

In general, the theoretical approach regarding to Public Debt is based on the establishment of Neoclassical theory, a theory which shows the negative connection between Public Debt and Economic Growth. In case Private Savings are not equal to National Savings, then it is necessary to do further adjustments in order to bring balance to National Savings, GDP and net foreign investments. Even if domestic capital remains unchanged, as well as the GDP, the 
future of GNP will fall. In this scenario, interest rates remain unchanged, assuming that capital inflow is immensely resilient. If capital inflow is not immensely resilient, then the government's inability to provide the perfect capital mobility may affect the decline in National Savings and may exert pressure on interest rates, directly affecting the decline in net foreign investments according to Elmendorf and Mankiw (1999).

Reinhart and Rogoff (2010), argues its non-linear relationship, characterized by a threshold effect between public debt and growth in a cross-country panel in 44 economies, categorized into four categories, debt below $30 \%$ of GDP, between 30 to $60 \%$ of GDP, between 60 to $90 \%$ of GDP, or above $90 \%$ of GDP. Main findings show that median growth rate for countries with public debt over $90 \%$ of GDP is around one percentage point yearly lower than countries with below $90 \%$.

Other economists argue that high levels of public debt have a negative impact on economic growth and that fiscal consolidation is necessary to anchor expectations and restore confidence (Cochrane, 2011b).

On the other hand, authors Caner et al. (2010) and Elmeskov and Sutherland (2012) found this debt threshold to be lower, at around 70\%. Further, lower debt threshold of 40 per cent has been evidenced by Hansen (2017), while Minea and Parent (2012) have estimated 115 per cent debt threshold.

Most of the studies are concerned with supporting, questioning, or rejecting the conclusions stated in the study of Reinhart and Rogoff, R\&R hereinafter. In this direction, Panizza and Presbitero (2012) have concluded that no single debt threshold exists that can separate the 'bad' from the 'good'. In addition, they claimed that R\&R oversimplified the relationship between debt and GDP growth, since no possible single threshold can be applied to each country.

Lof and Malin (2014) find no evidence of any strong effect between Public Debt and Economic Growth, even if there are high levels of Public Debt, there is still no significant impact on Economic Growth. Meanwhile Woo and Kumar (2015), in their study, have also tried to analyze other factors or variables that have a certain effect on the economic growth of countries. Additionally, Baum et al. (2013) in his scientific analysis reveals something similar that can be compared even with the studies conducted by Checherita, where according to his findings it is concluded that the low level of Public Debt could have a positive impact on Economic Growth and ascertains that Public Debt in the short-term periods, tends to have a positive impact on the economic growth of countries.

In addition, Chudik et al. (2015) concludes that some economies have run into debt difficulties and experienced low growth at low debt levels, while others at high levels of indebtedness for prolonged periods have grown strongly, thus, the effect of debt on growth varies among countries.

Bexheti et al (2020) in their research The Impact of Public Debt on Economic Growth: Empirical Analyses for Western Balkan Countries over the time (2003 - 2016) showed that short-run estimation results, in almost all specifications and models, indicate that public debt is weakly negatively correlated with economic growth of the sample countries, but the coefficient is only statistically significant in random effects as well as in 2SLS model. The quadratic term of debt is also included in the model, reflecting the nonlinear relationship of debt and growth. Its results disclose a maximum debt threshold of 50.87\%. While the causality test reveals a uni-directional relationship, meaning that public debt does not cause real GDP growth, whereas GDP growth causes public debt.

In time series data, Atique and Malik (2012) study examined the impact of domestic debt and external debt on Pakistan's economic growth over time (1980-2010). The results showed a negative impact of public debt on the economic growth of Pakistan, emphasizing that the increase of public debt both inside and outside does not give a positive effect on economic growth. Unlike other authors Bader and Magableh (2009) during a scientific analysis have identified the determinants of public debt in Jordan. Ahmed (2015) has researched the impact of external debt on Iraq's economic growth over time (1980-2014). The results showed a negative impact of external debt on GDP in the short and long run. Concretely, the eventual increase of public debt both in the short and long term has a negative impact on economic growth. Boboye and Ojo (2012) have studied the effect of external debt on economic growth in Nigeria. The findings in this study showed a negative effect of external debt on the country's income, and per capita income.

\section{METHODOLOGY, DATA AND MODEL}

This paper analyzes theories and work of the public debt ratio and economic growth, including developed countries and countries in transition. These secondary data, which are reviewed by various authors, are published in international impact conferences. A special focus in this paper is the theory of Reinhard and Rogof for the public debt threshold and the positive and negative impacts of economic growth.

The empirical evidence was made from the secondary data which were received by the Ministry of Finance and the Central Bank in Kosovo.

\section{Vector Autoregressive $V A R$ Models Analysis}

The autoregressive vector model is used to analyze many economic time series at a time (Zivot \& Wang, 2006). The vector autoregression (VAR) is used to assess the interrelationship between the economic time series and to analyze the dynamic effect of random disturbances on the variables system (Sujit \& Kumar, 2011). The VAR approach sidesteps the need for structural modeling by treating each endogenous variable in the system as a 
function of the lagged values of all the system's endogenous variables (Rahman \& Hossain, 2014). The VAR process is defined as;

$$
y_{t}=A_{1} y_{t-1}+\cdots+A_{p} y_{t-p}+B x_{t}+u_{t}
$$

where $y_{t}$ is a $k$ vector of endogenous variables, $x_{t}$ is a $d$-vector of exogenous variables, $A_{1}, \ldots, A_{p}$ and $B$ are matrices of coefficients to be estimated, $u_{t}$ and is a vector of innovations that may be contemporaneously correlated but are uncorrelated with their own lagged values and uncorrelated with all of the right-hand side variables.

The VAR models are constructed in this study as:

$$
\begin{aligned}
& G D P_{t}=\alpha_{1}+\phi_{11} G D P_{t}+\phi_{12} P D_{t}+\phi_{13} G E_{t}+\varepsilon_{1 t} \\
& G D P_{t}=\alpha_{2}+\phi_{21} G D P_{t-1}+\phi_{22} P_{t}^{2}+\varepsilon_{2 t} \\
& G D P_{t}=\alpha_{3}+\phi_{31} G D P_{t-1}+\phi_{32} \text { Consump }_{t}+\phi_{33} \text { Gross }_{t}+\phi_{34} \text { FixedCap }_{t}+\varepsilon_{3 t}(4)
\end{aligned}
$$

Where,

$\mathrm{PD}=$ Public Debt

GDP $=$ Gross Domestic Product

$\mathrm{GE}=$ Government Expenditure

Consump $=$ Final Consumption

Gross $=$ Gross Saving

FixedCap $=$ Fixed Capital Formation

\section{EMPIRICAL RESULTS}

\section{Government Debt in Region Country}

According to the USAID report Between 2007 and 2015 Albania's gross government debt relative to GDP increased by $18.5 \%$, the B\&H's increased by $26.8 \%$., Macedonia's increased by 15.1 p.p., Montenegro's increased by $38.9 \%$ and Serbia's increased by $44 \%$ relative to GDP.

As a result, Albania's government debts exceed $70 \%$ of GDP in 2015, and in Serbia close to $80 \%$ of GDP (a level similar to EU average government debt to GDP ratios). At the same time in Montenegro the pattern is close to that level and the trend is worsening. The situation in Montenegro and Serbia is more concerning as the need to reverse the trend of fast growing public debt is more pronounced (USAID, 2017)

Compared to countries in the region, Kosovo remains with low public debt regarding to GDP. From 2009 to 2015 , there was a moderate debt increase of $6.95 \%$.

\section{Government Debt in Republic of Kosovo}

Fig 1. Kosovo Government Debt To GDP (2009-2018 Data | 2019-2020 Forecast | Historical)

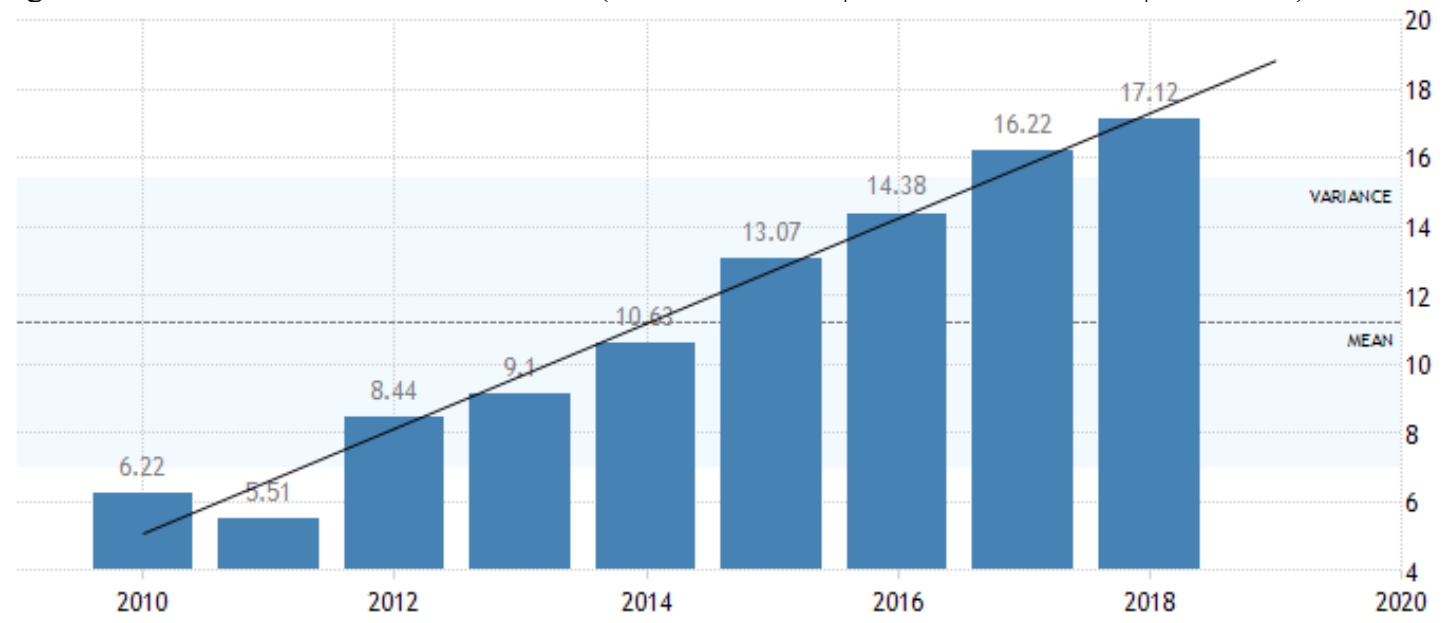

Source: https://tradingeconomics.com/ministry of financial/ Republic of Kosovo/

Graph 1 shows the public debt in the Republic of Kosovo to GDP and the growing debt trend as part of GDP. In 2010 the public debt was $6.22 \%$ of GDP, than then in 2011 there was a decline in 5.51\%. After 2011 the trend was increasing until present. In 2018, public debt was $17.12 \%$ to GDP. Kosovo's Government debt accounted for $17.5 \%$ of the country's Nominal GDP in 2019. 


\section{Empirical Results and Model}

Fig. 2 The graph shows that there has been a positive trend for the key economic indicator for Kosovo overtime.

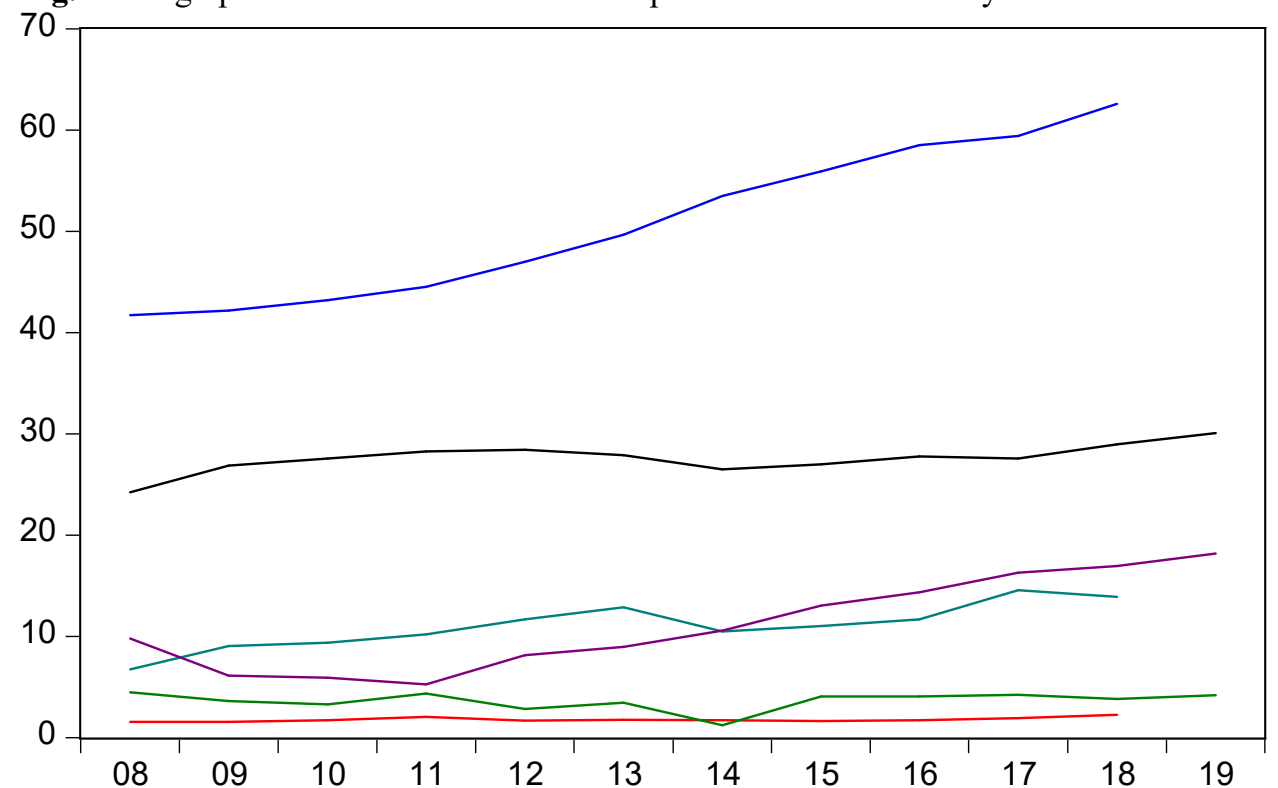

\section{Unit Root Test}

- Final consumption expenditure (constant LCU)
Fixed Capital Formation
GDP
Government Expenditures
Gross Saving
Public Debt

The Augmented Dickey-Fuller (ADF) formulae were employed to test for stationarity or the existence of unit roots in the data. The test results are as presented below:

Table 1: Augmented Dickey-Fuller Unit Root Test

\begin{tabular}{|l|l|l|l|l|l|}
\hline Series & $\begin{array}{l}\text { ADFR Test } \\
\text { Statistic }\end{array}$ & $\begin{array}{l}5 \% \\
\text { Values }\end{array}$ & $\begin{array}{l}10 \% \quad \text { Critical } \\
\text { values }\end{array}$ & Order & Remarks \\
\hline GDP & -3.361361 & -3.17532 & -2.728985 & $\mathrm{I}(0)$ & Stationary \\
\hline Public Debt & -1.385599 & -3.259808 & -2.771129 & $\mathrm{I}(2)$ & Stationary \\
\hline Final Consumption & 1.222478 & -3.212696 & -2.747676 & $\mathrm{I}(0)$ & Stationary \\
\hline Gross saving & -1.829618 & -3.212696 & -2.747676 & $\mathrm{I}(0)$ & Stationary \\
\hline $\begin{array}{l}\text { Fixed Capital } \\
\text { Formation }\end{array}$ & -1.105610 & -3.212696 & -2.747676 & $\mathrm{I}(0)$ & Stationary \\
\hline $\begin{array}{l}\text { Government } \\
\text { Expenditure }\end{array}$ & -0.726589 & -3.212696 & -2.747676 & $\mathrm{I}(1)$ & $\begin{array}{l}\text { Non- } \\
\text { stationary }\end{array}$ \\
\hline
\end{tabular}

The empirical tests on unit root test above shows that public debt and government expenditure were integrated to order 2 and 1 respectively. Considering the ADF test statistics at 5\% and 10\% critical values, it is observed that test statistics are greater (in absolute term) than the critical values. Thus, the series are said to be stationary at that level.

\section{Vector Autoregressive Model}

\section{Model 1:}

VAR system, lag order 1

OLS estimates, observations 2009-2019 $(\mathrm{T}=11)$

Log-likelihood $=-12.425041$

Determinant of covariance matrix $=0.56058255$

$\mathrm{AIC}=2.9864$

$\mathrm{BIC}=3.1311$

$\mathrm{HQC}=2.8952$

Portmanteau test: $\mathrm{LB}(2)=0.0829388, \mathrm{df}=1[0.7734]$ 
Equation 1: gdp

$\begin{array}{lllll} & \text { Coefficient } & \text { Std. Error } & \text { t-ratio } & p \text {-value } \\ \text { const } & -7.58106 & 8.94223 & -0.8478 & 0.4246 \\ \text { gdp_1 } & -0.219530 & 0.334132 & -0.6570 & 0.5322 \\ \text { PublicDebt } & 0.0149498 & 0.0705036 & 0.2120 & 0.8381 \\ \text { GovernmentExpenditu } & 0.421491 & 0.342835 & 1.229 & 0.2586\end{array}$
res

$\begin{array}{ll}\text { Mean dependent var } & 3.560455 \\ \text { Sum squared resid } & 6.166408 \\ \text { R-squared } & 0.251747 \\ \text { F }(3,7) & 0.785042 \\ \text { rho } & 0.016908\end{array}$

S.D. dependent var

0.907804

S.E. of regression

Adjusted R-squared

0.938571

$\mathrm{P}$-value(F)

$-0.068933$

Durbin-Watson

F-tests of zero restrictions:

All lags of gdp $\quad F(1,7)=0.43167[0.5322]$

$$
\begin{gathered}
G D P_{t}=-7.58106-0.219530 G D P_{t-1}+0.0149498 P U B L I C \_D E B T \\
+0.421491 G O V E R N M E N T \_E X P E N D I T U R E S
\end{gathered}
$$

This is the vector autoregressive model for GDP, it is explained and determined by the GDP in its first lag, public debt and government expenditure. Public debt is positively signed, indicating that an increase in public debt leads to increase in GDP are statistically not significant. Our results are in line with Savvides (1992); Kourtellos, Stengos, and Tan (2012) findings that suggest that there is no statistically significant relationship between debt and economic growth.

Also, government expenditure is positively signed, indicating that an increase in government expenditure leads to an increase in GDP are statistically not significant. Moreover, such results are in line with findings of Hsieh \& Lai (1994)

The value of $R^{2}(0.251747)$ shows that $(25 \%)$ variation in the GDP per capita is explained by the public debt and government expenditure. The value of adjusted $R^{2}$ squared $(-0.068933)$ shows it is not a good fit.

\section{Model 2:}

VAR system, lag order 1

OLS estimates, observations 2009-2018 $(\mathrm{T}=10)$

Log-likelihood $=-12.080447$

Determinant of covariance matrix $=0.65587329$

$\mathrm{AIC}=3.4161$

$\mathrm{BIC}=3.5674$

$\mathrm{HQC}=3.2501$

Portmanteau test: $\operatorname{LB}(2)=0.572807, \mathrm{df}=1[0.4491]$

Equation 1: gdp

$\begin{array}{lllll} & \text { Coefficient } & \text { Std. Error } & \text { t-ratio } & p \text {-value } \\ \text { const } & 0.966165 & 3.88804 & 0.2485 & 0.8136 \\ \text { gdp_1 } & -0.164044 & 0.406560 & -0.4035 & 0.7033 \\ \text { GrossSaving } & 0.0379603 & 0.201164 & 0.1887 & 0.0077 \\ \text { Finalconsumptionexpe } & -0.0143097 & 0.0740386 & -0.1933 & 0.0474 \\ \text { nditure } & & & \\ \text { FixedCapitalFormation } & 1.82967 & 2.16290 & 0.8459 & 0.0362\end{array}$

$\begin{array}{lclc}\text { Mean dependent var } & 3.496500 & \text { S.D. dependent var } & 0.930421 \\ \text { Sum squared resid } & 6.558733 & \text { S.E. of regression } & 1.145315 \\ \text { R-squared } & 0.558182 & \text { Adjusted R-squared } & 0.515272 \\ \mathrm{~F}(4,5) & 0.234882 & \text { P-value(F) } & 0.032297 \\ \text { rho } & 0.007657 & \text { Durbin-Watson } & 1.918089\end{array}$

F-tests of zero restrictions:

All lags of gdp $\quad F(1,5)=0.16281[0.7033]$ 


$$
\begin{aligned}
G D P_{t}= & 0.966165-0.164044 G D P_{t-1}-0.0143097 F I N A L_{-} C O N S U M P T I O N_{-} E X P E N D \\
& +0.0379603 G R O S S_{-} S A V I N G+1.82967 F I X E D \_C A P I T A L_{-} F O R M A T I O N
\end{aligned}
$$

This is the vector autoregressive model for GDP, it is explained and determined by the GDP in its first lag, fixed capital formation, gross saving and final consumption expenditure. Fixed capital formation is positively signed, indicating that an increase in fixed capital formation leads to increase in GDP and are statistically significant. This result is consistent with findings of Kormendi \& Meguire (1985); Barro (1991); Levine and Renalt (1992); Gibescu (2010).

Gross saving is positively signed, indicating that an increase in gross saving leads to increase in GDP per capita and are statistically significant. results that are corresponding with findings of several authors such as Bacha (1990); Otani and Villanueva (1990); DeGregorio (1992); Jappelli and Pagano (1994); Krieckhaus (2002).

Final consumption expenditure is negatively signed, indicating that an increase in final consumption expenditure leads to a decline in GDP per capita and are statistically significant, these results are in line with findings of $\operatorname{Kim}(2017)$.

The value of $R^{2}(0.558182)$ shows that (55.8\%) variation in the GDP per capita is explained by fixed capital formation, gross saving and final consumption expenditure. The value of adjusted $R^{2}$ squared (0.515272) shows it is a good fit.

Fig. 3: Optimal growth-maximising public debt threshold for Kosovo

\section{Marginal Plot of GDP vs Ratio}

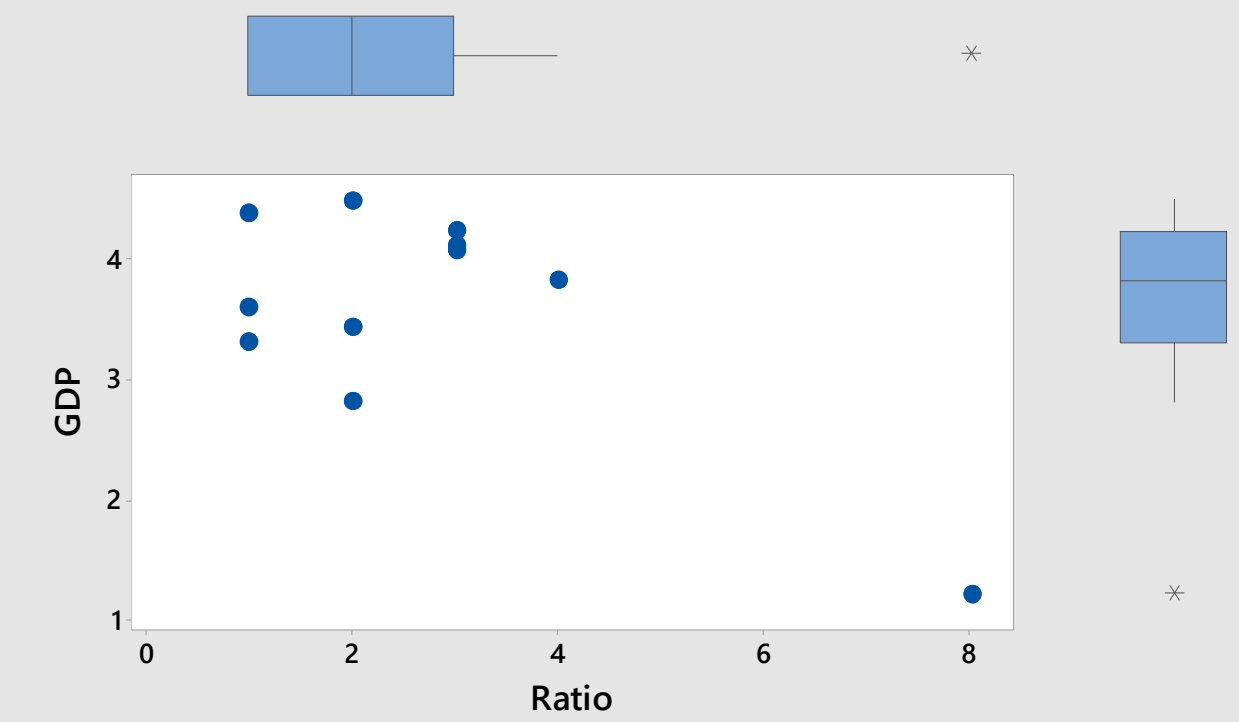

The chart in Figure 3 depicts a relationship between economic growth rates and the public debt-to-GDP ratio. The results suggest that Kosovo achieved higher growth rates when the public debt-to-GDP ratio was around 1030 percent. Assuming that the past provides a reasonable guide to the future, the 10-30 percent range could be considered an optimal growth-maximising public debt threshold for Kosovo.

\section{CONCLUSION}

The findings in this paper show the impact between public debt and economic growth in the Republic of Kosovo in the period from 2008 to 2018 . The R program was used to find empirical results and the data are from the Central Bank of Kosovo and the International Monetary Fund.

This study has potential limitation. Firstly, the time period of the research is shortly (2008-2018), the results in the model would be more accurate if the time period of the research had monthly data for these years, so the largest number of observations affects in accuracy results. Secondly, testing the data in the econometric model have not been able to include all the variables related to public debt and economic growth, such as: public investment, foreign direct investment, government spending, and fiscal policy instruments.

With the VAR model, the measurements show that public debt has a positive impact on economic growth, but the results are insignificant. This result is in line with Savvides (1992); Kourtellos, Stengos, and Tan (2012). Public debt square is positively signed, indicating that an increase in public debt square leads to increase in GDP are statistically not significant. 
Assuming that the past provides a reasonable guide to the future, the 10-30 percent range could be considered an optimal growth-maximising public debt threshold for Kosovo.

Government expenditure is positively signed, indicating that an increase in government expenditure leads to an increase in GDP are statistically not significant. Moreover, such results are in line with findings of Hsieh \& Lai (1994).

Fixed capital formation is positively signed, indicating that an increase in fixed capital formation leads to increase in GDP and are statistically significant. This result is consistent with findings of Kormendi \& Meguire (1985); Barro (1991); Levine and Renalt (1992); Gibescu (2010).

Gross saving is positively signed, indicating that an increase in gross saving leads to increase in GDP per capita and are statistically significant. results that are corresponding with findings of several authors such as Bacha (1990); Otani and Villanueva (1990); DeGregorio (1992); Jappelli and Pagano (1994); Krieckhaus (2002).

Final consumption expenditure is negatively signed, indicating that an increase in final consumption expenditure leads to a decline in GDP per capita and are statistically significant, these results are in line with findings of Kim (2017).

\section{REFERENCES}

[1]. Afonso, A, and Alves, J, 2015. The Role of Government Debt in Economic Growth, Hacienda Pública Española, Review of Public Economics, 215-(4/2015): 9-26 (C) 2015, Instituto de Estudios Fiscales DOI: 10.7866/HPE-RPE.15.4.1).

[2]. Ahmed, Y., Saeed. S., \& Saed, S. ,2015. The Impact of External Debt on Economic Growth : Empirical Evidence, Iraq. International Journal of Science and Research, 4(8), 1506-1516.

[3]. Annual Bulletin 2017 on Public Debt, Ministry of Finance, 2018

[4]. Atique, R., \& Malik, K. (2012). Impact of domestic and external debt on the economic growth of Pakistan. World Applied Sciences Journal, 20(1), 120-129.

[5]. Bacha, E. L. (1990). A three-gap model of foreign transfers and the GDP growth rate in developing countries. Journal of Development economics, 32(2), 279-296.

[6]. Bader, M., \& Magableh, I. K. (2009). An enquiry into the main determinants of public debt in Jordan: An econometric study. Dirasat, Administrative Sciences, 36(1), 181-190.

[7]. Baum A., Checherita-Westphal C. and Rother P. (2013). Debt and growth: new evidence for the euro area, Journal of International Money and Finance, vol. 32, pp. 809-21.

[8]. Bexheti, A., Sadiku, L., \& Sadiku, M. (2020). The Impact of Public Debt on Economic Growth: Empirical Analyses for Western Balkan Countries. In Economic and Financial Challenges for Balkan and Eastern European Countries (pp. 13-32). Springer, Cham.

[9]. Boboye A .L and Ojo A .M (2012) Effect of External Debt on Economic Growth and Development of Nigeria International Journal of Business and Social Science Vol. 3(2).

[10].Calderón, C., \& Fuentes, J. R. (2013). Government debt and economic growth (No. IDB-WP-424). IDB Working Paper Series.

[11].Caner M., Grennes T. and Koehler-Geib F. (2010). Finding the tipping point: when sovereign debt turns bad', in Braga C. A. P., editor; and Vincelette G. A., editor. (eds), Sovereign Debt and the Financial Crisis: Will this Time be Different? World Bank, pp. 63-75.

[12]. Cecchetti S. G., Mohanty M. S. and Zampolli F. (2011): Achieving growth amid fiscal imbalances: the real effects of debt, Federal Reserve Bank of Kansas City Proceedings, pp. 145-96.

[13]. Checherita-Westphal, C. and P. Rother (2012). The impact of High Government Debt on Economic Growth and its Channels: An Empirical Investigation for the Euro Area. European Economic Review 56(7), pp. 1392 -1405 .

[14].Chudik, A., Mohaddes, K., Pesaran, M. H., \& Raissi, M. (2015). Is there a debt-threshold effect on output growth? The Review of Economics and Statistics, 99(1), pp.135-150.

[15].Cochrane, J. H. (2011). Understanding policy in the great recession: Some unpleasant fiscal arithmetic. European Economic Review, 55(1), 2-30.

[16]. Cristina Checherita and Philipp Rother, The Impact of high and Growing Government Debt on Economic Growth an Empirical Investigation for the Euro Area,2010

[17].De Gregorio, J. (1992). Economic growth in latin america. Journal of development economics, 39(1), 59-84.

[18].Égert. B (2015), 90\% public debt threshold: The rise and fall of a stylized fact. Applied Economics, Vol.47, No.34/36, pp 3756-3770

[19].Elmendorf, D.W., and Mankiw, N. G., (1999). Actural Budget defict expectations and interest rates. In Handbook of Macroeconomics, Vol. 1c, ed. J.B. Taylor and M. Woodford, chapter 25. Amsterdam. Elsevier Science.

[20].Elmeskov J. and Sutherland D. (2012). Post-crisis debt overhang: growth implications across countries, conference paper at Reserve Bank of India's second international research conference, Paris: OECD 
Economics Department.

[21]. Gibescu, O. (2010). Does the gross fixed capital formation represent a factor for supporting the economic growth?.

[22].Gómez-Puig M., Sosvilla-Rivero, S. (2015), On the be directional causal relationship between public debt and economic growth in EMU countries. University of Barcelona Research Institute of Applied Economics Working Paper, 2015/12 1/32.

[23].Hansen B. E. (2017). Regression kink with an unknown threshold', Journal of Business and Economic Statistics, vol. 35, pp. 228-40.

[24].Hsieh, E., \& Lai, K. S. (1994). Government spending and economic growth: the G-7 experience. Applied Economics, 26(5), 535-542.

[25].Jappelli, T., \& Pagano, M. (1994). Saving, growth, and liquidity constraints. The Quarterly Journal of Economics, 109(1), 83-109.

[26].Kormendi, R. C., \& Meguire, P. G. (1985). Macroeconomic determinants of growth: Cross-country evidence. Journal of Monetary economics, 16(2), 141-163.

[27].Kourtellos, A., Stengos, T., \& Tan, C. M. (2013). The effect of public debt on growth in multiple regimes. Journal of Macroeconomics, 38, 35-43..

[28].Krieckhaus, J. (2002). Reconceptualizing the developmental state: public savings and economic growth. World development, 30(10), 1697-1712.

[29].Kumar M. S and Woo J. (2010). Public debt and growth, IMF Working paper no. 10(174), Washington, DC: International Monetary Fund.

[30].Levine, R., \& Renelt, D. (1992). A sensitivity analysis of cross-country growth regressions. The American economic review, 942-963.

[31].Lof dhe Malinen (2014). Does Sovereing debt weaken economic growth? A panel VAR analysis Economics Letters, Vol. 122, No.3, pp.403-407

[32]. Mencinger, Jernej \& Verbic, Miroslav \& Aristovnik, Aleksander, (2015). Revisiting the role of public debt in economic growth: The case of OECD countries. MPRA Paper 67704, University Library of Munich, Germany

[33]. Minea, A., \& Parent, A. (2012). Is high public debt always harmful to economic growth? Reinhart and Rogoff and some complex nonlinearities. CERDI, 2012.

[34]. Otani, I., \& Villanueva, D. (1990). Long-term growth in developing countries and its determinants: An empirical analysis. World Development, 18(6), 769-783.

[35].Panizza, U. and A. F. Presbitero (2013). Public Debt and Economic Growth in Advanced Economies: A Survey. Swiss Journal of Economics and Statistics 149(II), pp. 175-204.

[36].Panizza, U., \& Presbitero, A. F. (2013). Public debt and economic growth in advanced economies: A survey. Swiss Journal of Economics and Statistics, 149(2), 175-204.

[37].Panizza, U., \& Presbitero, A. F. (2013). Public debt and economic growth, one more time. VoxEU. org, 25.

[38].Rahman, Z., \& Hossain, M. E. (2014). Role of agriculture in economic growth of Bangladesh: A VAR approach. Journal of Business, 7, 163-185

[39]. Reinhart, C. M. and K. S. Rogoff (2010). Growth in a Time of Debt. American Economic Review 100(2), pp. $573-78$

[40]. Robert J. Barro, R.J, 1979. On the Determination of the Public Debt, The Journal of Political Economy, Vol. 87, No. 5, Part 1. (Oct., 1979), pp. 940-971).

[41].Savvides, A. (1992). Investment slowdown in developing countries during the 1980s: Debt overhang or foreign capital inflows?. Kyklos, 45(3), 363-378.

[42].Sujit, K. S., \& Kumar, B. R. (2011). Study on dynamic relationship among gold price, oil price, exchange rate and stock market returns. International journal of applied business and economic research, 9(2), 145-165.

[43].USAID report for Western Balkan, Regional Economic Growth Project, 2017

[44]. Woo,J. and Kumar M.S (2015). Public Debt and Growth, Wiley Online Library (https://onlinelibrary.wiley.com/doi/full/10.1111/ecca.12138)

[45]. Yang, W. S., Park, B. W., Jung, E. H., Jeon, N. J., Kim, Y. C., Lee, D. U., ... \& Seok, S. I. (2017). Iodide management in formamidinium-lead-halide-based perovskite layers for efficient solar cells. Science, 356(6345), 1376-1379.

[46].Zivot, E., \& Wang, J. (2006). Vector autoregressive models for multivariate time series. Modeling financial time series with S-PLUS $®$, 385-429 